ISSN 1392-3196 / e-ISSN 2335-8947

Zemdirbyste-Agriculture, vol. 101, No. 4 (2014), p. 431-436

DOI 10.13080/z-a.2014.101.055

\title{
Cold tolerance of Colorado potato beetle (Leptinotarsa decemlineata Say) adults and eggs
}

\author{
Külli HIIESAAR, Reet KARISE, Ingrid H. WILLIAMS, Anne LUIK, Luule METSPALU, \\ Katrin JÕGAR, Viacheslav EREMEEV, Angela PLOOMI, Eha KRUUS, Marika MÄND \\ Institute of Agricultural and Environmental Sciences, Estonian University of Life Sciences \\ Kreutzwaldi 1, 51014 Tartu, Estonia \\ E-mail: kylli.hiiesaar@emu.ee
}

\begin{abstract}
The cold tolerance of different seasonal groups (pre-diapause, diapauses and post-diapause) of Colorado potato beetle (Leptinotarsa decemlineata Say) was assessed by exposing them either to a constant temperature of $-3^{\circ} \mathrm{C}$ for 48 to $624 \mathrm{~h}$, or to $-3,-4,-5,-6$ or $-7{ }^{\circ} \mathrm{C}$ for a constant $24 \mathrm{~h}$. Cold survival was affected by the length of exposure, by the temperature rates and by seasonality. The least cold-tolerant were pre-diapause beetles in August with a mean lethal temperature (Ltemp50) of $-4.4^{\circ} \mathrm{C}$ for $24 \mathrm{~h}$ exposure and with a lethal time (Ltime50) of $106.8 \mathrm{~h}$ at $-3^{\circ} \mathrm{C}$. Cold tolerance was significantly higher in the diapause group in January and in the post-diapause group in March; it did not differ significantly between these groups of beetle for $24 \mathrm{~h}$ exposure, the lethal temperature being $-5.8^{\circ} \mathrm{C}$ for both groups. Seasonality had a greater influence on survival of these groups after longer exposure to constant mild sub-zero temperature $\left(-3^{\circ} \mathrm{C}\right)$; in diapause group, all the beetles survived $624 \mathrm{~h}$ exposure, but in post-diapause group the survival limit decreased to $216 \mathrm{~h}$ and lethal time was $153.9 \mathrm{~h}$. Colorado potato beetle eggs tolerated $24 \mathrm{~h}$ exposure to sub-zero temperatures from $-3^{\circ} \mathrm{C}$ to $-5^{\circ} \mathrm{C}$ or longer exposure at $-3^{\circ} \mathrm{C}$ for $72 \mathrm{~h}$ without a reduction in hatchability. The mean lethal time for $50 \%$ mortality of eggs was $76.5 \mathrm{~h}$ and mean lethal temperature was $-5.8^{\circ} \mathrm{C}$. Thus, we conclude that night frosts common in northern regions do not damage Colorado potato beetle adults or eggs to the extent that might threaten the survival of the population.
\end{abstract}

Key words: cold tolerance, exposure temperatures, exposure time hatchability, seasonality.

\section{Introduction}

The information about lethal temperatures for active or overwintering Colorado potato beetles (Leptinotarsa decemlineata Say) throughout their distribution area is poor or largely unknown (Boiteau, Coleman, 1996). There are diverse data concerning the supercooling ability (from -3 to $-20{ }^{\circ} \mathrm{C}$ ) of Colorado potato beetles estimated by different authors (Lee et al., 1994; Boiteau, Coleman, 1996; Hiiesaar et al., 2001). Still these earlier studies have demonstrated that the supercooling ability of many insects is not completely associated with their cold tolerance because of the prefreeze mortality above the supercooling points (Nedvěd, 2000; Koštal et al., 2004).

Reported studies concerning the cold tolerance of Colorado potato beetles from different geographical regions indicate that beetles from higher latitudes are usually more cold-tolerant than those from lower latitudes (Chen, Kang, 2004). According to earlier investigations, Colorado potato beetles from northern regions can only tolerate temperatures some degrees below zero (Ushatinskaja, 1981). Probably the beetles currently inhabiting these areas have become more coldtolerant since their arrival. Unfortunately, we have no records about the cold tolerance of the beetles found first in southern regions of Estonia in 1965. Colorado potato beetles were not able to establish for many years as they all died out during winter; in the subsequent two decades only new immigrant beetles were found occasionally in potato fields. However, by the mid 80 -s the beetles were already able to overwinter successfully in southern regions of Estonia (Hiiesaar et al., 2006). This concurs with the general observation on establishment of insects in a new environment that after accidental introduction 15 to 20 generations are required for entrenched establishment in a suitable area (Pests and Diseases Image Library, 2014).

Expansion of Colorado potato beetles habitat has not finished yet and during the last decade the beetles have been found hibernating also in northern regions of Estonia (our unpublished data).

Winter is the most dangerous but not the only critical period in the life of Colorado potato beetles. Many insects are able to increase their cold tolerance seasonally, which enhances their winter survival (Bale, 1996). Overwintering in the soil in a diapause state by itself guarantees the cold survival of Colorado potato beetles (Danks, 1987). Beetles are most vulnerable to unfavourable environmental conditions when in their active state. In northern regions, the adults, as well as the preimaginal stages of Colorado potato beetles are often exposed to low temperatures even in the growing season. In Estonia $\left(57^{\circ} 30^{\prime}-59^{\circ} 40^{\prime} \mathrm{N}, 21^{\circ} 45^{\prime}-28^{\circ} 15^{\prime} \mathrm{E}\right)$, night frosts are common almost throughout the growing period (Tarand et al., 2013). Therefore, cold tolerance is an important physiological trait for survival of Colorado potato beetles at any season.

Investigations have shown that Colorado potato beetle larvae can well tolerate temperatures below the developmental threshold; over $50 \%$ of larvae survived 
after 6 days of exposure to $7.5^{\circ} \mathrm{C}$ (Hiiesaar et al., 2005). Even sub-zero treatment had only a minor effect on larval mortality as after $3 \mathrm{~h}$ exposure to $-4^{\circ} \mathrm{C}$ only $1.2 \%$ of individuals perished (Lyytonen et al., 2009). There are some records concerning the response of Colorado potato beetle eggs to low temperatures but these investigations dealt with temperatures below the developmental threshold not sub-zero temperatures (Boiteau, Alford, 1983).

The current investigation should enable the capacity of Colorado potato beetle adults and eggs to survive in conditions severely deviated from the optimum to be determined. We studied how seasonality affects the cold tolerance of Colorado potato beetles 1) after exposure to different periods of time to constant moderate sub-zero temperature and 2) after exposure to different sub-zero temperatures for a constant period of time. We also studied the cold survival of Colorado potato beetle eggs at different sub-zero temperatures and exposure times.

\section{Material and methods}

The experiments were performed at different times in 2012-2013. All the beetles and eggs were collected from the organic potato plots of medium late potato variety 'Reet' grown in the experimental field which was firstly established in 2008 near Tartu (Estonia). The beetles collected at the end of August were examined within $24 \mathrm{~h}$ after sampling. The beetles collected during September from the soil and from harvested potato haulms were stored until usage in trials in a refrigerator at $5 \pm 0.5^{\circ} \mathrm{C}$ in 11 glass jars filled with moist soil.

Cold tolerance of beetles was measured three times: first in August when the beetles were accomplishing their pre-winter maturity feeding; second in late December and mid-January during their intense diapause period and third in March after termination of diapause. The hibernating beetles were removed from the refrigerator directly before using them in the experiment.

To determine the effect of low temperatures and exposure duration on survival of adult Colorado potato beetles (Leptinotarsa decemlineata Say), the beetles were exposed either for $24 \mathrm{~h}$ to one of five different temperature regimes: $-3,-4,-5,-6$ and $-7{ }^{\circ} \mathrm{C}$ or to a constant $-3^{\circ} \mathrm{C}$ for different periods of time from 48 to $624 \mathrm{~h}$. Each treatment was replicated three times with 45 60 beetles in each test. The beetles were enclosed in glass vials lined with filter paper with each beetle isolated from others with thin paper. Constant cooling and warming rates were achieved using a liquid thermostat "Ministat 230w-2" ("Huber", Germany). The vials were cooled at a rate of $0.5^{\circ} \mathrm{C} \mathrm{h}^{-1}$ down to the required temperature, followed by warming to room temperature at the same rate. Each glass vial was supplied with a thermocouple to register temperature; temperature fluctuation inside the vials did not exceed $\pm 0.2^{\circ} \mathrm{C}$. Beetles were examined 2 and $24 \mathrm{~h}$ after transfer to room temperature, and classified into one of two groups: fit and unviable. Beetles in the fit group recovered within 2 to $24 \mathrm{~h}$, moved normally and did not reveal any sign of damage, whereas those in the unviable group were heavily cold-injured or dead; beetles that did not respond to tactile stimulation $24 \mathrm{~h}$ after rewarming were considered dead whereas those that moved their antennae and legs but were not able to walk were considered cold-injured. The latter were observed until all of them had died.

Egg clutches of Colorado potato beetle were gathered in mid-July from the same potato field. The age of egg masses was unknown. To evaluate their survival at sub-zero temperatures, the egg clutches were exposed to $-3^{\circ} \mathrm{C}$ for $24,48,72,96$ and $120 \mathrm{~h}$ or to $-3,-4,-5,-6$ and $-7^{\circ} \mathrm{C}$ for $24 \mathrm{~h}$. There were three replicates at all cooling regimes and each replicate included one egg clutch with a varying number of eggs in it. After treatment, the egg masses were removed from the thermostat, counted and placed on Petri dishes lined with moist filter paper and subjected to the $22^{\circ} \mathrm{C} \ldots 24^{\circ} \mathrm{C}$ temperature. Egg mortality and hatching success was recorded daily for about two weeks. Non-hatched eggs were dissected to determine whether any embryonic development had been initiated or any morphological changes had occurred.

Statistical analyses. A difference in survival rate of beetles depending on temperatures or exposure times was calculated by Kruskal-Wallis ANOVA. Differences in survival of Colorado potato beetle eggs were tested by one way $A N O V A$ LSD test. Mean lethal temperature at which $50 \%$ of beetles died (Ltemp50) when exposed for a constant $24 \mathrm{~h}$ to different low sub-zero temperatures or lethal time (Ltime50) after exposure to $-3^{\circ} \mathrm{C}$ for different periods of time were calculated by probit analyses (StatPlus 2009, AnalystSoft Inc.).

\section{Results}

Effect of exposure time on the survival of beetles. The cold survival of beetles after exposure to a constant $-3^{\circ} \mathrm{C}$ for different periods of time (from 48 to $624 \mathrm{~h}$ ) is presented in Figure 1 and the mean lethal time required for $50 \%$ mortality (Ltime50) - in Table 1 . Probit analyses data did not enable estimation of lethal time in December-January because there was no mortality after any exposure of beetles to this temperature.

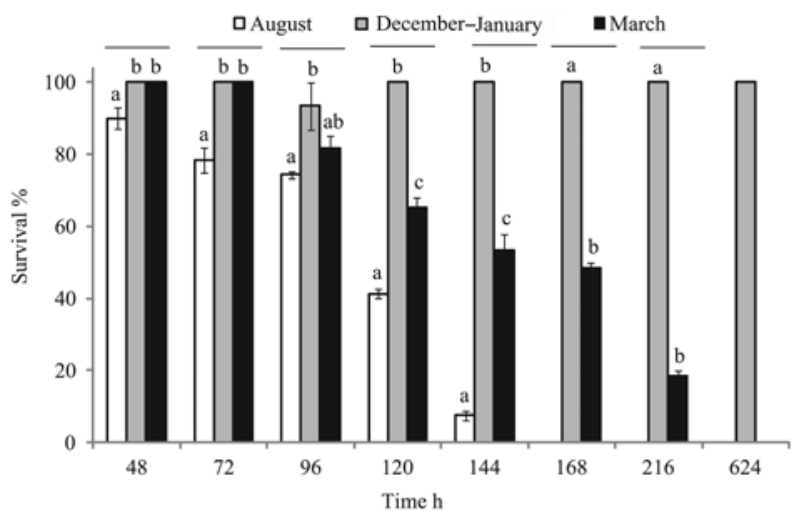

Note. Different letters above the columns indicate differences in survival between seasonal groups for each exposure time (Kruskal-Wallis ANOVA, LSD $-p<0.05$ )

Figure 1. Mean $( \pm \mathrm{SE})$ survival of Colorado potato beetles after exposure to constant $-3^{\circ} \mathrm{C}$ for different periods of time

Seasonality affected the cold survival of Colorado potato beetle adults. The most tolerant were the beetles in December-January, the exposure time had no effect on survival in this group; there was no mortality even after the longest exposure $(624 \mathrm{~h})$ we used $(\mathrm{H}(7, \mathrm{~N}=24), p=$ 0.42 ). The beetles were most cold susceptible in August during the pre-winter maturity feeding as they started to die already after $48 \mathrm{~h}$ exposure. Statistical analyses show that, if the exposure time increased, survival decreased $(\mathrm{H}(4, \mathrm{~N}=15)=12.9, p=0.01)$. Survival limit for these beetles was $144 \mathrm{~h}$, Ltime50 was $106.8 \mathrm{~h}$. In March, all the beetles survived for 48 and $72 \mathrm{~h}$, but started to die after $96 \mathrm{~h}$ exposure. The survival decreased with increased exposure $(\mathrm{H}(6, \mathrm{~N}=21)=19.4, p=0.003)$, survival limit for this group was $216 \mathrm{~h}$ and Ltime 50 was $153 \mathrm{~h}$. 
Table 1. Mean lethal time required for $50 \%$ mortality (Ltime50) of Colorado potato beetles after exposure to constant $-3^{\circ} \mathrm{C}$ for different periods of time

\begin{tabular}{cccc}
\hline Date & $\begin{array}{c}\text { Number of } \\
\text { beetles }\end{array}$ & $\begin{array}{c}\text { Ltime } 50 \\
\mathrm{~h}\end{array}$ & $\begin{array}{c}95 \% \\
\text { confidence limits }\end{array}$ \\
\hline August & 381 & $106.8 \mathrm{a}$ & 101.2 to 112.4 \\
March & 303 & $153.9 \mathrm{~b}$ & 144.4 to 163.7 \\
\hline
\end{tabular}

Note. $\mathrm{a}, \mathrm{b}$ - different letters within a column indicate significant differences between groups of different measuring dates based on overlap of their $95 \%$ confidential limits.

Effect of different low temperatures on survival of beetles. Cold survival of beetles after $24 \mathrm{~h}$ exposure to different sub-zero temperatures (from -3 to $-7^{\circ} \mathrm{C}$ ) is presented in Figure 2. Probit analysis data, with mean lethal temperature required for $50 \%$ mortality (Ltemp50) are presented in Table 2 .

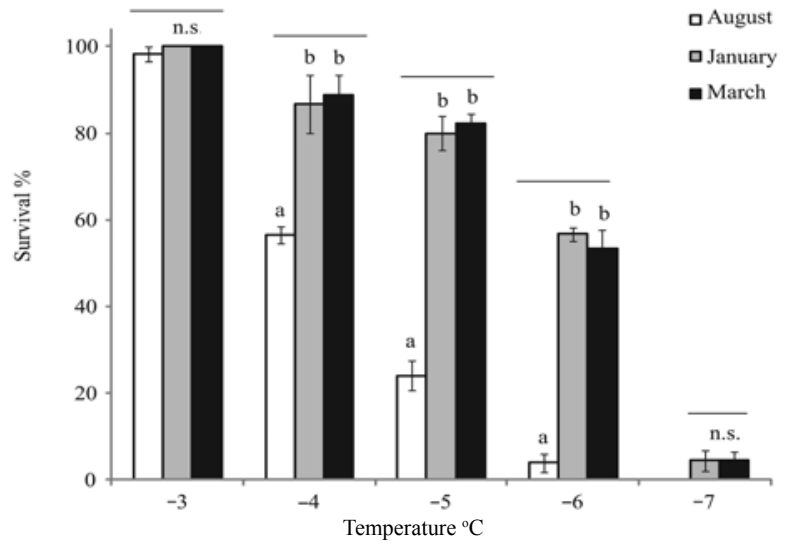

Note. Different letters above the columns indicate significant differences in survival measured at different times of the year (Kruskal-Wallis ANOVA, LSD test $-p<0.05$ ).

Figure 2. Mean ( \pm SE) survival of Colorado potato beetles after exposure to different sub-zero temperatures for $24 \mathrm{~h}$

Table 2. Mean lethal temperatures required for $50 \%$ mortality (Ltemp50) of Colorado potato beetles after $24 \mathrm{~h}$ exposure to different sub-zero temperatures

\begin{tabular}{cccc}
\hline Date & $\begin{array}{c}\text { Number of } \\
\text { beetles }\end{array}$ & $\begin{array}{c}\text { Ltemp50 } \\
{ }^{\circ} \mathrm{C}\end{array}$ & $\begin{array}{c}95 \% \\
\text { confidence limits }\end{array}$ \\
\cline { 4 - 5 } August & 247 & $-4.4 \mathrm{a}$ & -4.0 to -4.6 \\
January & 242 & $-5.8 \mathrm{~b}$ & -5.5 to -6.1 \\
March & 240 & $-5.8 \mathrm{~b}$ & -5.5 to -6.0 \\
\hline
\end{tabular}

Note. $\mathrm{a}, \mathrm{b}-$ the different letters within a column indicate significant differences between groups of different measuring dates based on overlap of their $95 \%$ confidential limits.

All the beetles survived $24 \mathrm{~h}$ exposure at $-3^{\circ} \mathrm{C}$ irrespective of the assessment data. Two hours after rewarming they were active and walking normally. If the temperature decreased they started to die in all groups (Kruskal-Wallis ANOVA test: August, $\mathrm{H}(4, \mathrm{~N}=15)=$
$13.4, p=0.009 ;$ January $\mathrm{H}(4, \mathrm{~N}=15)=13.1, p=0.01$; March, $\mathrm{H}(4, \mathrm{~N}=15)=13.2, p=0.01)$. The beetles were most cold susceptible in August: less than half of them survived at $-4^{\circ} \mathrm{C}$, few survived at $-6^{\circ} \mathrm{C}$, none survived at $-7^{\circ} \mathrm{C}$; lethal temperature was $-4.4^{\circ} \mathrm{C}$. The survival of the beetles from January and March groups did not vary in any of the temperatures tested: over $80 \%$ of beetles survived at $-4^{\circ} \mathrm{C}$ and $-5^{\circ} \mathrm{C}$, the survival limit for both groups was $-7^{\circ} \mathrm{C}$; lethal temperature was $-5.8^{\circ} \mathrm{C}$. Death of some beetles did not occur immediately after cold treatment; after re-warming they stayed alive for 7 to 40 days, but never recovered entirely.

Effect of exposure time on hatchability of eggs. Cold survival of eggs after exposure at $-3^{\circ} \mathrm{C}$ for different periods of time presented in Figure 3 indicated that exposure time affected hatchability $\left(\mathrm{F}_{3: 12}=364, p=0.00\right)$. Probit analyses data with mean lethal time (Ltime50) required for $50 \%$ mortality of eggs are presented in Table 3 .

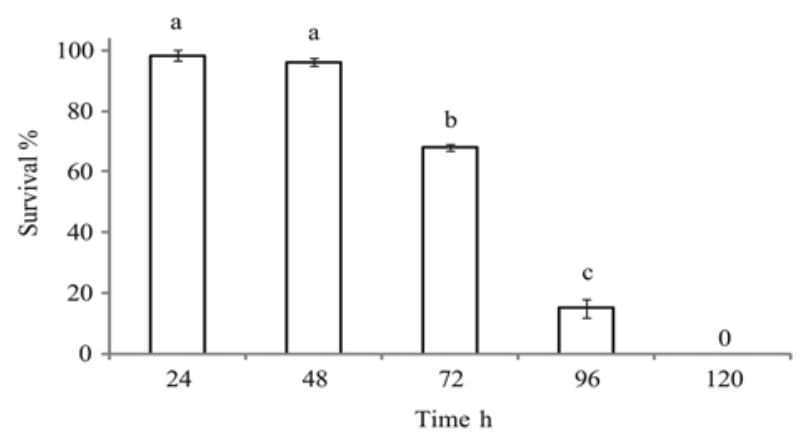

Note. Different letters above the columns indicate significant differences in survival of eggs after exposure to different periods of time (one way $A N O V A$, LSD test $-p<0.05$ ).

Figure 3. Mean $( \pm \mathrm{SE})$ survival of Colorado potato beetle eggs after exposure to $-3^{\circ} \mathrm{C}$ for different periods of time

Exposure for 24 and $48 \mathrm{~h}$ did not affect embryonic development; there were very minor differences between hatchability of eggs at these two temperature rates $(p>$ 0.05). Despite completing their embryonic development successfully, some larvae were not able to emerge from the egg shell because of their unfavourable location (some eggs were covered with other eggs). As exposure time increased, survival decreased. After $72 \mathrm{~h}$ exposure, $60 \%$ of eggs had completed their embryonic development. After $96 \mathrm{~h}$, their survival decreased drastically with less than 20\% larvae hatching; although embryonic development was mostly completed the larvae were not able to chew through the chorion and died. After $120 \mathrm{~h}$ exposure, no embryogenesis occurred. Mean lethal time required for $50 \%$ mortality of eggs after exposure to $3^{\circ} \mathrm{C}$ was $76.5 \mathrm{~h}$.

Effect of different low temperatures on hatchability of eggs. Cold survival (= hatchability) of Colorado potato beetle eggs after $24 \mathrm{~h}$ exposure to various sub-zero temperatures is presented in Figure 4. Temperature affected egg hatchability significantly $\left(\mathrm{F}_{3.16}=5.890, p=0.007\right)$. Probit analysis data about the

Table 3. Mean lethal temperatures (Ltemp50) and mean lethal time (Ltime50) required for 50\% mortality of Colorado potato beetle eggs after exposure at different sub-zero temperatures for $24 \mathrm{~h}$ and to constant $-3^{\circ} \mathrm{C}$ for different periods of time (probit analysis data)

\begin{tabular}{ccccccc}
\hline Date & $\mathrm{N}$ & $\begin{array}{c}\text { Ltemp50 } \\
{ }^{\circ} \mathrm{C}\end{array}$ & $\begin{array}{c}95 \% \text { confidence } \\
\text { limits }\end{array}$ & Number of eggs & $\begin{array}{c}\text { Ltime } 50 \\
\mathrm{~h}\end{array}$ & $\begin{array}{c}95 \% \text { confidence } \\
\text { limits }\end{array}$ \\
\hline July & 493 & 5.8 & -5.7 to -6.1 & 761 & 76.5 & 73.5 to 79.6 \\
\hline
\end{tabular}


exposure temperature that resulted in $50 \%$ mortality of eggs (Ltemp50) are presented in Table 3.

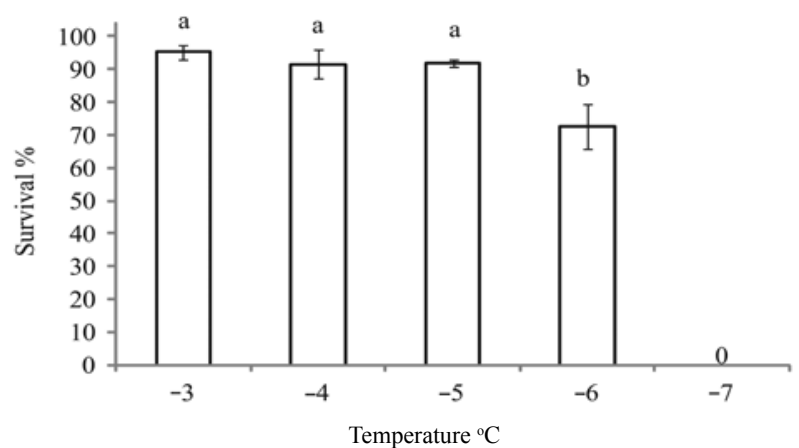

Note. Different letters above the columns indicate significant differences in survival of eggs at different temperatures (one way $A N O V A$, LSD test $-p<0.05$ ).

Figure 4. Mean $( \pm \mathrm{SE})$ survival of Colorado potato beetle eggs after exposure to different sub-zero temperatures for $24 \mathrm{~h}$

Temperatures $-3,-4$ and $-5{ }^{\circ} \mathrm{C}$ had little effect on egg embryonic development with no differences in hatchability after $24 \mathrm{~h}$ exposure $(p>0.05)$. Less than $10 \%$ of larvae did not hatch although their embryonic development was completed successfully; there were perfect larvae inside the egg shells. If the temperature decreased to $-6^{\circ} \mathrm{C}$, hatchability dropped significantly, at $-7^{\circ} \mathrm{C}$, embryonic development did not occur and the apical part of egg had become transparent. Mean lethal temperature required for $50 \%$ mortality of eggs after $24 \mathrm{~h}$ exposure was $-5.8^{\circ} \mathrm{C}$.

\section{Discussion}

Our results indicate that cold resistance in the Colorado potato beetles in Estonia has developed to the extent that eradication of this pest is hardly possible. This physiological trait is important for its survival at any season. Some temperatures applied in our trials were somewhat lower than the adults and eggs probably encounter in nature during the growing period or during winter.

Effect of different low temperatures and exposure time on survival of beetles. Earlier studies have shown that the cold tolerance of insects changes with season (Koštal, Šimek, 1995) and is parallel to the change in the intensity of diapause (Boiteau, Coleman, 1996). Our results confirmed that pre-diapause beetles in August were the most cold susceptible. At that time, the acclimation and formation of diapause was still ongoing. Increase in cold tolerance of many insects develops after a period of acclimation at low temperatures and some physiological modifications acquired through this improve cold resistance (Overgaard et al., 2008). Boiteau and Coleman (1996) found that diapause by itself increased cold tolerance in Colorado potato beetles even without acclimation; reduction of the gut content and increase in the amount of body fat is responsible for lowering the low temperature exotherm by a few degrees. We saw increasing cold survival of beetles in December or January during the intense diapause period. The beetles also maintained their ability to withstand short exposure to low temperatures after termination of diapause in March during the post-diapause quiescence period. We did not find a significant difference in survival of beetles at any temperature in January or March.

The physiological state of the beetles was characterized by their behaviour at different periods of the experiment. In August, the beetles continued feeding as they were still in their pre-diapause period. In January, they started to re-burrow into the soil, a reliable indicator of reproductive diapause in Colorado potato beetles (Hare, 1990). In March, the beetles stayed on the soil surface and started to eat and mate, indicating that diapause had terminated.

Our investigations established that seasonality had greater influence on survival of beetles after longer exposure to constantly mild sub-zero temperature $\left(-3^{\circ} \mathrm{C}\right)$ than after short exposure $(24 \mathrm{~h})$ to somewhat lower temperatures. Nedvěd (1998) has also demonstrated that moderately low temperatures below the developmental threshold might induce injuries in the absence of freezing if the exposure time is sufficiently long. Accumulation of cold injuries that prove to be fatal depended on the duration of exposure; at longer exposures chill injuries accumulated irreversibly (Renault et al., 2004). The most cold-tolerant to long exposure were the beetles in deep diapause in January, as none died or showed chill injuries after 26 day exposure at $-3^{\circ} \mathrm{C}$. In March, after termination of diapause, the beetles started to die after 4 days' exposure. Active beetles in August were very sensitive to the extended cold exposure; they began to die already after 2 days' exposure and mortality increased drastically after each treatment.

The Colorado potato beetles proved to be very vital. Temperatures $-5 \ldots-6{ }^{\circ} \mathrm{C}$ did not kill any beetles immediately; serious injuries led to mortality in longer time course, some of them remained alive for up to two months. This phenomenon has also been described by Kung et al. (1992) who found that mortality at $-6^{\circ} \mathrm{C}$ and $-8^{\circ} \mathrm{C}$ was not expressed immediately after cold shock. Injury symptoms refer to damage to the nervous and muscular system, which, according to Kelty et al. (1996), is the most sensitive to chill injury. Cold treated beetles were able to move their antennae but their legs were paralyzed. Chill coma recovery time is widely accepted as an ecologically relevant measure of resistance to low temperature (Hoffmann et al., 2003; Marais, Chown, 2008). After short exposure, some chill injuries are reversible when the insects return to higher temperatures (Renault et al., 2004), but, in our trials, few injured beetles recovered entirely with time.

On the basis of the present investigations and other published data, the cold tolerance of Colorado potato beetle adults varies in different geographical populations. According to Kung et al. (1992) in Wisconsin, longer exposure to $-4^{\circ} \mathrm{C}$ was lethal for most overwintering beetles. At the same temperature rate, our overwintering beetles survived $24 \mathrm{~h}$ cooling without notable loss; but at $-3^{\circ} \mathrm{C}$ there was no mortality in diapausing beetles even after 26 days of exposure. Our records with active beetles concur with those of Costanzo et al. (1997), where mortality of beetles exposed to $-5^{\circ} \mathrm{C}$ for $24 \mathrm{~h}$ varied between $36 \%$ and $78 \%$ depending on the substrate. It is difficult to compare our results with those of Boiteau and Coleman (1996) where 50\% of overwintering Colorado potato beetles survived $3 \mathrm{~h}$ exposure to $-7^{\circ} \mathrm{C}$ in New Brunswick because the exposure time in our trial was considerably longer.

Usually the overwintering beetles may not encounter the sub-zero temperatures we used in our experiments as the snow cover provides good protection against freezing. We registered the temperatures in overwintering places of beetles in 2010-2011; the lowest temperature was $-0.4^{\circ} \mathrm{C}$ on the soil surface and $-0.2^{\circ} \mathrm{C}$ at a depth of $15 \mathrm{~cm}$ (Hiiesaar et al., 2013). This is notably higher than the diapausing or post-diapausing beetles 
could tolerate after long exposure in the experiment. Still, during the last decade there was one extremely harsh snowless winter in 2002-2003. In that year, survival depended on soil type where the beetles hibernated; in clay loam all the beetles perished whereas in sandy loam approximately 15\% survived (Hiiesaar et al., 2006).

Effect of low temperatures on embryonic development. The Colorado potato beetle eggs tolerated well short exposure to sub-zero temperatures as low as $-3^{\circ} \mathrm{C} \ldots-6^{\circ} \mathrm{C}$ or longer exposure at $-3^{\circ} \mathrm{C}$ for $72 \mathrm{~h}$. Longterm weather data indicate that, in some years during recent decades, temperatures in Estonia fell to $-6^{\circ} \mathrm{C}$ in May and to $-2.5^{\circ} \mathrm{C}$ in June (Tarand et al., 2013). This coincides with the time when the Colorado potato beetle adults emerge from the soil and start to oviposit (Hiiesaar et al., 2013). Embryogenesis begins when temperatures rise to $10 \ldots 12.5^{\circ} \mathrm{C}$ (Tauber et al., 1988). The harmful effect of low temperature depends on temperature rate and exposure time; the short-term effect of very low temperatures is considered equivalent to the long-term effect of mild temperatures (Sømme, 1996). In our experiment, one day of sub-zero treatment at $-6^{\circ} \mathrm{C}$ was equal to three days at $-3^{\circ} \mathrm{C}$; following incubation at room temperature over $70 \%$ of eggs completed embryogenesis and the larvae hatched without any damage. With longer exposure time or lower temperature survival decreased. After 4 days' exposure at $-3^{\circ} \mathrm{C}$, most of the larvae could not emerge, despite completed embryogenesis with perfect larvae inside egg shells. Emergence is considered the most critical period in the development of eggs; according to Cline (1971), mortality occurs mainly at this time. If the exposure time extended to 5 days at $-3^{\circ} \mathrm{C}$ or temperature fell to $-7^{\circ} \mathrm{C}$ after $24 \mathrm{~h}$ exposure embryonic development did not occur. Pathological structural changes of eggs could be observed even through the egg shells; the apical part of the eggs became transparent. Failure of embryonic development at low temperature may be due to cryoinjuries or dehydration (Hadley, 1994).

Boiteau and Alford (1983) found that the cold tolerance of Colorado potato beetle eggs can be affected by their age; freshly laid eggs are very sensitive to low temperature. The embryonic development of Colorado potato beetles is divided into 16 morphological stages and the sensitivity of eggs to unfavourable factors can change within a few hours (Kittlaus, 1961). The variability in the survival of eggs between different replicates in our trials could be explained by the differences in their age. Besides age, survival within the same egg mass varied also as the individuals in each population may show variation in their response to different suboptimal factors.

In our unstable weather conditions Colorado potato beetles may be exposed to the impact of sub-zero temperatures at all developmental stages. Mild longlasting or lower short-lasting sub-zero temperatures did not damage eggs or adults to an extent that might threaten the survival of the population, certainly they damage potato leaves and thereby the food conditions of larvae and adult. At present, it seems that, as Colorado potato beetle has colonised such extensive areas in our country, eradication of this pest seems unlikely.

\section{Conclusions}

1. The most tolerant to different exposure time were diapausing Colorado potato beetles (Leptinotarsa decemlineata Say) in December-January as no mortality was observed after exposure at $-3^{\circ} \mathrm{C}$ for $624 \mathrm{~h}$. The most cold susceptible were the pre-diapause Colorado potato beetles in August with a mean lethal time (Ltime50) of
$106.8 \mathrm{~h}$. In March, during the post-diapause period the mean lethal time was $154 \mathrm{~h}$.

2. The most susceptible to different sub-zero temperatures after $24 \mathrm{~h}$ exposure were the Colorado potato beetles in August with a mean lethal temperature (Ltemp50) of $-4.4^{\circ} \mathrm{C}$. In January and March, the Colorado potato beetles tolerated short exposure to different subzero temperatures equally; lethal temperature was $-5.8^{\circ} \mathrm{C}$ in both groups.

3. Mean lethal time required for $50 \%$ mortality (Ltime 50) of Colorado potato beetle eggs after exposure to $-3^{\circ} \mathrm{C}$ was $76.5 \mathrm{~h}$, and the mean temperature required for $50 \%$ mortality of eggs (Ltemp 50 ) after $24 \mathrm{~h}$ exposure was $-5.8^{\circ} \mathrm{C}$.

4. Night frosts common in northern regions do not damage Colorado potato beetle adults or eggs to the extent that might threaten the survival of the population.

\section{Acknowledgements}

This study was supported by the grants 9449 , 9450 and 8895 of the Estonian Science Foundation, the Estonian Ministry of Education and Research-targeted financing project No. SF 0170057s09 and CORE organic II TILMAN-ORG project.

Received 29012014 Accepted 21082014

\section{References}

Bale J. S. 1996. Insect cold hardiness: a matter of life and death. European Journal of Entomology, 93: 369-382

Boiteau G., Alford A. 1983. Synchronization of Colorado potato beetle (Coleoptera: Chrysomelidae) emergence by temporary storage of eggs at low temperature. Canadian Entomologist. 115: 1233-1234 http://dx.doi.org/10.4039/Ent1151233-9

Boiteau G., Coleman W. 1996. Cold tolerance in the Colorado potato beetle, Leptinotarsa decemlineata (Say) (Coleoptera: Chrvsomelidae). Canadian Entomologist, 128: 1087-1099 http://dx.doi.org/10.4039/Ent1281087-6

Chen B., Kang L. 2004. Variation in cold hardiness of Liriomyza huidobrensis (Diptera: Agromyzidae) along latitudinal gradients. Environmental Entomology. 33 (2):155-164 http://dx.doi.org/10.1603/0046-225X-33.2.155

Cline D. L. 1971. Indian meal moth eggs hatch and subsequent larval survival after short exposures to low temperature. Journal of Economic Entomology, 63 (4): 1081-1083

Costanzo J. P., Moore J. B., Lee R. L., Kaufman P. E., Wyman J. A. 1997. Influence of soil hydric parameters on the winter cold hardiness of the borrowing beetle, Leptinotarsa decemlineata (Say). Journal of Comparative Physiology B, 167: 169-176 http://dx.doi.org/10.1007/s003600050061

Danks H. V. 1987. Insect dormancy: an ecological perspective. Biological Survey of Canada (Terrestrial Arthropods). Ottawa, Canada, $439 \mathrm{p}$.

Hadley N. F. 1994. Water relations of terrestrial arthropods. San Diego, New York, Boston, London, Sydney, Tokio, Toronto, $355 \mathrm{p}$

Hare J. D. 1990. Ecology and management of the Colorado potato beetle. Annual Review of Entomologv. 35 (1): 81-100 http://dx.doi.org/10.1146/annurev.en.35.010190.000501

Hiiesaar K., Kuusik A., Jõudu J., Metspalu L., Hermann P. 2001. Laboratory experiments on cold acclimation in overwintering Colorado potato beetles, Leptinotarsa decemlineata (Say). Norwegian Journal of Entomology, 48: 87-90

Hiiesaar K., Metspalu L., Jõudu J., Jõgar K. 2005. Influence of low temperatures on development of preimaginal stages of Colorado potato beetles Leptinotarsa decemlineata (Say) (Coleoptera: Chrysomelidae). Egyptian Journal of Agricultural Research, 83 (2): 707-718

Hiiesaar K., Metspalu L., Jõudu J., Jõgar K. 2006. Over-wintering of the Colorado potato beetle (Leptinotarsa decemlineata Say) in field conditions and factors affecting its population density in Estonia. Agronomy Research, 4 (1): 21-30 
Hiiesaar K., Jõgar K., Williams I. H., Kruus E., Metspalu L., Luik A., Ploomi A., Eremeev V., Karise R., Mänd M. 2013. Factors affecting development and overwintering of second generation Colorado Potato Beetle (Coleoptera: Chrysomelidae) in Estonia in 2010 http://dx.doi.org/10.1080/09064710.2013.811536

Hoffmann A. A., Hallas R. J., Dean J. A., Schiffer M. 2003. Low potential for climatic stress adaptation in a rainforest Drosophila species. Science. 301 (5629): 100-102 http://dx.doi.org/10.1126/science.1084296

Kelty J., Killian K. A., Lee R. E. 1996. Cold shock and rapid coldhardening of pharate adultflesh flies (Sarcophaga crassipalpis), effects on behaviour and neuromuscular function following eclosion. Phvsiological Entomology. 21: 283-288 http://dx.doi.org/10.1111/j.1365-3032.1996.tb00866.x

Kittlaus E. 1961. Die Embryonalentwicklung von Leptinotarsa decemlineata Say, Epilachna sparsa Herbst und Epilachna vigintioctomaculata Motsch var. niponica Lewis. Abhangigkeit von der Temperatur. Deutsche Entomologische Zeitschrift, 8: 41-62 (in German)

Koštal V., Šimek P. 1995. Dynamics of cold hardiness, supercoiling and cryoprotectants in diapausing and nondiapausing pupae of the cabbage root fly, Delia radicum $\mathrm{L}$. European Journal of Entomology, 7: 627-634

Koštal V., Vambera J., Bastl J. 2004. On the nature of pre-freeze mortality in insects: water balance, ion homeostasis and energy charge in the adults of Pyrrhocoris apterus. Journal of Experimental Biology. 207: 1509-1521 http://dx.doi.org/10.1242/jeb.00923

Kung K.-J. S., Milner M., Wyman J. A., Feldman J., Nordheim E. 1992. Survival of Colorado potato beetle (Coleoptera: Chrysomelidae) after exposure to sub-zero thermal shocks during diapause. Journal of Economic Entomology, 85 (5): 1695-1700 (6)

Lee R. E., Costanzo J. P., Kaufman P. E., Lee M. R., Wyman J. A. 1994. Ice-nuclating active bacteria reduce cold-hardiness of the freeze-intolerant Colorado potato beetle (Coleoptera, Chrysomelidae). Journal of Economical Entomology, 87 (2): $377-381$
Lyytonen A., Boman S., Grapputo A., Lindström L., Mappes J. 2009. Cold tolerance during larval development: effects on the thermal distribution limits of Leptinotarsa decemlineata. Entomologia Experimentalis et Applicata. 133: 92-99 http://dx.doi.org/10.1111/j.1570-7458.2009.00908.x

Marais E., Chown S. L. 2008. Beneficial acclimation and the Bogert effect. Ecology Letters, 11: 1027-1036 http://dx.doi.org/10.1111/j.1461-0248.2008.01213.x

Nedvěd O. 1998. Modelling the relationship between cold injury and accumulated degree days in terrestrial arthropods. CryoLetters, 19: 267-274

Nedvěd O. 2000. Snow white and seven dwarfs: a multivariate approach to classification of cold tolerance. CryoLetters, 21: $339-348$

Overgaard J., Tomcala A., Sorensen J. G., Holmstrup M., Krogh P. H.,Šimek P., Koštal V. 2008. Effects of acclimation temperature on thermal tolerance and membrane phospholipid composition in the fruit fly Drosophila melanogaster. Journal of Insect Physiology. 54 (3): 619$629 \mathrm{http}: / / \mathrm{dx}$.doi.org/10.1016/j.jinsphys.2007.12.011

Pests and Diseases Image Library 2014. http://pbt.padil.gov.au/pbt/ index.php?q=node/23\&pbtID=92 [accessed 1001 2014]

Renault D., Nedved O., Hervant F., Vernon P. 2004. The importance of fluctuating thermal regimes for repairing chill inj injures in the tropical beetle Alphitobius diaperinus (Coleoptera: Tenebrionidae) during exposure to low temperature. Physiological Entomology, 29: 139-145 http://dx.doi.org/10.1111/j.0307-6962.2004.00377.x

Sømme L. 1996. The effect of prolonged exposures at low temperatures in insects. CryoLetters, 17: 341-346

Tarand A., Jaagus J., Kallis A. 2013. Estonian climate in past and present. Tartu University, 630 p. (in Estonian)

Tauber M. J., Tauber C. A., Obrycki J. J., Gollands B., Wright R. J. 1988. Voltinism and the induction of aestival diapause in the Colorado potato beetle Leptinotarsa decemlineata Say (Coleoptera, Chrysomelidae). Annals of Entomological Society of America, 81 (5): 748-754

Ushatinskaja R. S. 1981. Prolonged diapause in Colorado potato beetle, Leptinotarsa decemlineata (Say). Moscow, Russia, 375 p.

ISSN 1392-3196 / e-ISSN 2335-8947

Zemdirbyste-Agriculture, vol. 101, No. 4 (2014), p. 431-436

DOI $10.13080 / \mathrm{z}-\mathrm{a} .2014 .101 .055$

\title{
Kolorado vabalo (Leptinotarsa decemlineata Say) suaugèlių ir kiaušinèlių atsparumas šalčiui
}

\author{
K. Hiiesaar, R. Karise, I. H. Williams, A. Luik, L. Metspalu, K. Jõgar, V. Eremeev, \\ A. Ploomi, E. Kruus, M. Mänd
}

Estijos gyvybès mokslų universiteto Žemès ūkio ir aplinkos mokslų institutas

\section{Santrauka}

Kolorado vabalo (Leptinotarsa decemlineata Say) ịvairių (prieš diapauzę, diapauzès ir po diapauzès) sezoninių grupių atsparumas šalčiui vertintas juos laikant pastovioje $-3{ }^{\circ} \mathrm{C}$ temperatūroje nuo 48 iki $624 \mathrm{~h}$ ir skirtingoje $-3,-4,-5$, -6 arba $-7{ }^{\circ} \mathrm{C}$ temperatūroje $24 \mathrm{~h}$. Išgyvenimui šaltyje turèjo ịtakos vabalų ekspozicijos laikas, temperatūros lygis ir jų sezoniškumas. Jautriausi šalčiui buvo vabalai, surinkti prieš diapauzę rugpjūčio mėnesị, kai letalinè temperatūra (Ltemp50) buvo $-4,4{ }^{\circ} \mathrm{C}$, o poveikio laikas $-24 \mathrm{~h}$, taip pat $106,8 \mathrm{~h}$ juos veikiant $-3{ }^{\circ} \mathrm{C}$. Vabalų atsparumas šalčiui buvo esmingai didesnis diapauzès grupeje sausio mènesị ir grupeje po diapauzès kovo mènesị; jis esmingai nesiskyre tarp šiu grupių, kai abiem grupèms poveikio laikas buvo $24 \mathrm{~h}$, o Ltemp $50--5,8^{\circ} \mathrm{C}$. Vabalų grupių sezoniškumas (prieš diapauzę, diapauzès metu ir po diapauzès) turèjo didesnès įtakos šių grupių išgyvenimui po ilgos ekspozicijos pastovioje nedidelèje minusineje $\left(-3^{\circ} \mathrm{C}\right)$ temperatūroje; diapauzès grupëje visi vabalai išgyveno $624 \mathrm{~h}$, grupejje po diapauzès išgyvenimo riba sumažèjo iki $216 \mathrm{~h}$, o letalinis laikas (Ltime50) buvo 153,9 h. Kolorado vabalo kiaušinèliai toleravo $24 \mathrm{~h}$ poveiki minusine nuo $-3 \mathrm{iki}-5{ }^{\circ} \mathrm{C}$ temperatūra arba ilgesnę $72 \mathrm{~h}$ ekspoziciją $-3{ }^{\circ} \mathrm{C}$ temperatūroje, kiaušinèlių ritimasis nesumažejo. Kiaušinèlių mirtingumui $(50 \%)$ vidutinis Ltime50 buvo 76,5 h, o vidutinẻ Ltemp $50--5,8^{\circ} \mathrm{C}$. Taigi galima daryti išvadą, kad naktinès šalnos, ịprastos šiauriniuose regionuose, kolorado vabalų suaugèliams ar kiaušinèliams nepakenkia tokiu mastu, kad keltų grèsmę populiacijos išlikimui.

Reikšminiai žodžiai: atsparumas šalčiui, kiaušinèlių ritimasis, sezoniškumas, veikimo laikas, veikimas temperatūra. 